\title{
Towards sustainable forest management in the European Union through polycentric forest governance and an integrated landscape approach
}

\author{
Marius Lazdinis $\mathbb{D} \cdot$ Per Angelstam $\cdot$ Helga Pülzl
}

Received: 13 April 2018/Accepted: 16 May 2019/Published online: 16 July 2019

(C) The Author(s) 2019

\begin{abstract}
Context Achieving sustainable development as an inclusive societal process, and securing sustainability and resilience of human societies as well as the natural environment are wicked problems. Realising sustainable forest management (SFM) policy in local landscapes is one example.

Objectives Using the European Union as a case study for the implementation of SFM policy across multiple governance levels in different contexts, we discuss the benefits of adopting an integrated landscape approach with place and space, partnership and sustainability as three pillars.
\end{abstract}

The authors stating that the contents represents only the authors' views.

\section{Lazdinis}

Directorate-General for Agriculture and Rural

Development, European Commission, Brussels, Belgium

M. Lazdinis · P. Angelstam ( $\square)$

Faculty of Forest Sciences, School for Forest

Management, Swedish University of Agricultural

Sciences, PO Box 43, 73921 Skinnskatteberg, Sweden

e-mail: per.angelstam@slu.se

H. Pülzl

Institute of Forest, Environmental, and Natural Resource Policy, University of Natural Resources and Life Sciences Vienna (BOKU), and European Forest Institute - Forest Policy Research Network, Feistmantelstrasse 4,

1180 Vienna, Austria
Methods We map the institutional frameworks for implementing SFM policy within all EU member states. Next, we analyse whether or not there is EUlevel forest governance, and how power is distributed among EU, member state and operational levels.

Results Mechanisms to steer a centralized forest governance approach towards SFM in the EU are marginal. Instead, there is a polycentric forest governance with 90 national and sub-national governments, which create and implement own and EU-wide SFMrelated policies. Additionally, both among and within regional governance units there is a large variation in governance arrangements linked to land ownership at the operational level.

Conclusions To effectively translate EU-wide SFM and SFM-related policies into action in local landscapes, it is crucial to acknowledge that there are different land ownership structures, landscape histories and alternative value chains based on multiple ecosystem services. Therefore regionally adapted landscape approaches engaging multiple stakeholders and actors through evidence-based landscape governance and stewardship towards sustainable forest landscape management are needed. Model Forest, Long-Term Socio-Ecological Research platform and Biosphere Reserve are three of many examples.

Keywords Ecosystem services · European Union · Land ownership · Landscape history · Region · Value chain 


\section{Introduction}

The dominating natural potential vegetation type of the European Union (EU) is forest (Bohn et al. 2000). Throughout Millennia, large areas of other wooded land of cultural origins also developed (e.g., Agnoletti 2013). Today, these two groups of land cover types occupy $182 \mathrm{M}$ ha (43\%) of the European Union's (EU) land area, of which $134 \mathrm{M}$ ha are available for wood supply (Eurostat 2017). Forest and other wooded land are regionally very diverse with respect to their biophysical properties (Bohn et al. 2000), landscape histories (Kirby and Watkins 2015) and land ownership (Pulla et al. 2013; Eurostat 2017). These land covers host biodiversity in terms of species, habitats and ecological processes, all of which provide the supporting base for delivering other ecosystem services, including provisioning (wood, fibre and other natural resources for the wood-based industry and energy production), regulating (climate change mitigation and hydrological cycle regulation) and cultural (including a broad range of immaterial values that support human well-being). In some EU Member States, forestry and forest-based industries exporting value-added wood-based products are major employers within the manufacturing sector (Eurostat 2017). However, new forest jobs are increasingly also based on non-wood products, landscape and nature-based tourism and amenity values (Simpson et al. 2008). Attractive forest and wooded landscapes are valuable per se for people's perceived well-being (Elbakidze et al. 2017), and may be chosen as a preferred option for settling and commuting to jobs in urban areas (Lindelöw 2018).

These multiple, and often conflicting, benefits of forests and other wooded land increasingly demand integrated responses from policy-makers at multiple levels of governance. The interest in governance can be traced back to the end of 1990s, when Rhodes (1996, 1997) made his seminal contributions. According to Bell and Hindmoor (2012), two main accounts on governance have emerged since. The first is a society-centred one (Salamon 2002; Koppenjan and Klijn 2004; Rhodes 2007), and the second one is a state-centred perspective (e.g., Pierre and Peters 2000; Bell and Hindmoor 2009). Here we focus on the second point of view (Pierre and Peters 2000, p. 1) "the capacity [...] to make and implement policy-in other words, to steer society". This leads to interpreting forest governance as the capacity to make and implement forest and forest-related policy, i.e. to steer society towards attaining a broad range of objectives in landscapes and regions dominated by forest and other wooded land.

By and large, a long history of focusing on material aspects of forestry has been very successful in term of satisfying local needs (Elbakidze and Angelstam 2007), developing effective silvicultural systems (Puettmann et al. 2012) and providing industrial material (Eurostat 2008) and creating an effective wood-based value chain (e.g., Cambero and Sowlati 2014). However, regarding ecological, social and cultural SFM objectives, development of policy implementation instruments, strategic and tactical planning, and operational management lag behind (e.g., Kennedy et al. 2001; MCPFE 2006; Angelstam et al. 2011, 2018a; Parrotta and Trosper 2012; Beland Lindahl et al. 2017). Lately, new policy objectives, such as further intensification of forestry for climate change mitigation, have appeared and increasingly complicate already existing challenges of biodiversity conservation and rural development based on a diversity of ecosystem services (Edwards and Kleinschmit 2013; Beland Lindahl et al. 2017; EASAC 2017; Naumov et al. 2018). Intensification links closely to terms like bioeconomy, bio-based economy and knowledge-based bioeconomy (see McCormick and Kautto 2013; Aggestam et al. 2017), which are increasingly being used, and have potential of becoming a new influential forestry discourse (Pülzl et al. 2014). The role of forestry in climate change mitigation remains, however, contested (EASAC 2017). While younger and faster-growing forests may have a higher rate of carbon uptake from the atmosphere, it is the older, longer-rotation forests and protected oldgrowth forests that maintain the highest carbon stocks. On the other hand, effective substitution of fossil fuels and building with wood can reduce carbon emissions (Gustavsson and Sathre 2006). There are thus tensions between different SFM objectives; notably between increased production and extraction of forest biomass, and the contributions made by the same biomass to soil fertility, biodiversity and protective functions (Triviño et al. 2015; Angelstam et al. 2018b). Another topic to assess is the role of alternatives to wood-based forest value chains, which consider other economic, as well as ecological and social dimensions of SFM in time and space (e.g., Dittrich et al. 2017; Naumov et al. 
2018). Translating SFM policy objectives into action on the ground can thus be described as a "wicked problem" (e.g., Head 2008; Sayer et al. 2013; Duckett et al. 2016).

Several attempts to increase co-ordination and cooperation (and coherence) in forest and forest-related EU policy and decision-making have taken place in the EU context (Pülzl et al. 2013, 2018). The latest effort to strengthen coordination in 2013 resulted in a new EU Forest Strategy (European Commission 2013a, b). It aims at coordinating other EU policies that relate to forest policy. This soft form of coordination does, however, lack political power and direct funding (Pelli et al. 2012). Albeit no EU "common" forest policy was defined, a large range of policies and forest-related legislation developed in the meantime are impacting forests and forestry (Aggestam and Pülzl 2018). Therefore, multiple objectives apply in one or the other way also to EU forest governance. The meaning of sustainable forest management (SFM) has thus transitioned from single (wood and biomass) to multiple objectives (Pülzl et al. 2018), and from single local to multiple spatial scales of spatial planningfrom forest stands within forest management and local administrative units as well as regions (Kennedy et al. 2001; Muñoz-Rojas et al. 2015; Angelstam et al. 2018a, b). Additionally, governance is asymmetric between regional, member state and EU levels, which makes it difficult to coordinate and thus ensure coherent forest policy steering. Given the diversity of forest and woodland types and social-ecological systems in Europe, it is therefore important to understand how to translate forest and forest-related policies into action in different contexts, and to assess the consequences on the ground (e.g., Rauschmayer et al. 2009; Angelstam et al. 2013).

This article proposes that the landscape concept's different interpretations can contribute to regionally adapted knowledge production and learning about how to communicate and operationalise ecosystem services in forests and wooded lands and other land covers across Europe (Angelstam et al. 2013, 2019a in this special issue). The reason is that landscape captures the biophysical, anthropogenic and intangible dimensions of areas and places, where people live and work (Grodzynskyi 2005; European Science Foundation 2010; Angelstam et al. 2013). Our argumentation is dual. First, we review the institutional setting available for EU forest governance across multiple administrative levels and stakeholders. This is important, because without knowing who governs and has authority for forest policy and planning, coordination and cooperation in EU forest governance will remain a challenge. This calls for regionally adapted collaborative learning and landscape stewardship within the wide web of multiple actors that the EU's diverse regions and landscapes represent. Second, we discuss the opportunities to implement SFM on the ground by advocating and applying an approach based on landscape, with place and space, partnership and sustainability as three pillars (e.g., IMFN 2008).

\section{Three levels of forest governance in the European Union}

\section{The EU level}

Co-ordination, complementarity and coherence of forest and forestry-related actions between Member States (MS) and within the EU have for long been of interest to EU-level forest stakeholders (Council of the European Union 1999; Angelstam et al. 2004; Commission of the European Communities 2005a, b, c; European Commission 2013b, p. 87f; Pülzl et al. 2013; Aggestam and Pülzl 2018). In 1986, the policy on protection of forests against atmospheric pollution was adopted (Council Regulation (EEC) No. 3528/86 of 17 November 1986 on the protection of the Community's forests against atmospheric pollution). In 1992, the European Commission (EC) involvement in forests and forestry entered a more ambitious phase, strengthening measures to protect forests from atmospheric pollution and fires, and co-financing forestry research under the EU's research and development programmes in the fields of agricultural and environmental research (Regulations No. 2157/92 and No 2158/92). In 1995, the EU gained three new members with a high proportion of forest cover, namely Austria, Finland and Sweden. In 1998 the Council Resolution on a Forestry Strategy for the European Union (Council of the European Union 1999) was adopted. It aimed at establishing a framework for forest and forestry-related actions in support of SFM, based on the co-ordination of the forest policies of MS and Community policies and initiatives relevant to forests and forestry. The two Regulations (atmospheric pollution and forest fires) expired in 2002. The "Forest 
Focus" Regulation (2152/03) concerning monitoring of forests and environmental interactions entered into force in 2003, but expired already at the end 2006. To promote the integration of sustainable development within its trade policy and to stop illegal logging outside the Union, the EU formulated an Action Plan for Forest Law Enforcement, Governance and Trade (FLEGT) (Commission of the European Communities 2003 ) in 2003. Wood producing countries were invited to develop Voluntary Partnership Agreements with the Union to ensure that imported timber and timber products come from legal sources. In 2010, this Action Plan was complemented by a timber regulation that obliged respective importers and traders to know the source of wood or related product when importing them to the EU (European Parliament and of the Council of the European Union 2010). Through those activities, the EU attempted to coordinate its external trade relations with regards to import of wood and related products.

The EU Forest Action Plan, adopted in 2006 was another attempt to further increase co-ordination and co-operation (and coherence) in forest and forestrelated policy making (Commission of the European Communities 2006). Albeit some achievements reached, coordination still remained weak (Pelli et al. 2012). The latest attempt as described in the Forest Strategy (European Commission 2013a) aims at improving again coordination and coherence of forestrelated policies as well as enhancing public communication. Eight main priorities were therein identified that cluster in the following way: (1) contributing to major societal objectives (rural development, competitiveness, climate change, forest protection); (2) improving the knowledge base (information and monitoring, research and innovation) and (3) coordination and communication (working together, global perspective).

These policy deliberations resulted in a set of formal and ad hoc institutional formations enabling participation of interest groups and flow of information between the EC and stakeholders (Lazdinis et al. 2009). The objective was to co-ordinate and cooperate in the EC, between the EC and MS, and among MS, and to consult with the relevant forest-related interest groups. The Inter-Service Group on Forestry is another intra-institutional EC mechanism, established in 2001 to improve co-ordination among EC services responsible for relevant EU policies. Their main objective is to improve internal coherence to better exploit potential synergies among policy areas effecting forest management.

At the EU level, formal and ad hoc co-operation and communication with stakeholders largely takes place in the context of existing committees, which have a role of assisting the EC with technical expertise. There is a regular information exchange with forest and forestry-related stakeholders through the Civil Dialogue Group on forestry and cork. It includes representatives of forest owner organisations (public and private), forest-based industries, environmental NGOs, forest trade unions, traders and consumer groups. The Expert Group on Forest-based Industries and Sectorally Related Issues set up in 2014, involves representatives from the whole spectrum of EU forestbased industries, relevant MS authorities and groupings holding relevant information. This body is a channel for co-operation between the forest-based industries and the Commission. Other relevant committees and groups exist in relation to the Forest Law Enforcement Governance and Trade (FLEGT) and the Expert group on Natura 2000 management.

Co-ordination with MS takes place in three forms: (1) the Council Working Party on Forestry (CWPF), (2) the Standing Forestry Committee (SFC), and (3) the forestry Directors-General meetings. The EU MS and the EC co-ordinate positions prior to major forestrelated international meetings in the CWPF, which is part of the Council of Ministers as the principal meeting place of national governments and deals with forest-relevant policies and legislative initiatives. The SFC brings together MS representatives and is chaired by the Commission. It mainly acts as an ad hoc consultation forum that provides expertise in connection with the development of forest-related measures (e.g., on rural development, environment, water). It also provides a venue for exchange of information and technical expertise among MS, and between MS and the Commission. Successive Presidencies of the EU organise periodically informal meetings of DirectorsGeneral responsible for forestry in MS. The role of these bodies, maybe except for the CWPF, has remained more technical. The new Forest Strategy indicates the need for improving the SFC status (European Commission 2013a, p. 13). 
The member states and regions

In the EU, forest policy is the competence of national and or regional level legislators and executives, depending on the individual MS. It is in the hands of 90 legislatures and executives (Table 1). In at least six MS (Austria, Belgium, Germany, Italy, Spain, UK) forestry competence is to a large degree devolved to the sub-national/regional level. This diversity is consistent with a number of rural programmes under the EU rural development policy, which serve as a proxy measurement of the number of significant administrative bodies in charge of forest policy formulation and implementation. A total of 88 rural development programmes were submitted to the EC and used in rural development policy implementation during financial period 2007-2013 (European Commission 2008, 2009). In the period 2014-2020 there are 118 rural development programmes.

In about one third of the 90 executives, the competence in forests rests with the ministries of agriculture, and in another third it rests within the ministries of environment. The latter applies in particular to Spain, where in 14 out of 17 regions forestry is under the competence of the ministry of environment of some sort. Finally, in about one-third of the executives, forestry is part of the ministries with combined competences in agriculture, rural affairs and environment. This is particularly the case with German Länder ministries, except for Bavaria, having a Ministry for Food, Agriculture and Forestry.
Table 1 Division of competences in the area of forest policy in the EU member states

\begin{tabular}{|c|c|c|}
\hline Country & Competent institution on a sub-national level & Number of units \\
\hline Austria & Federal Ministry and District Administrations & 9 \\
\hline Belgium & Regional ministries & 2 \\
\hline Bulgaria & State ministry & 1 \\
\hline Cyprus & State ministry & 1 \\
\hline Croatia & State ministry & 1 \\
\hline Czechia & State ministry & 1 \\
\hline Denmark & State ministry & 1 \\
\hline Estonia & State ministry & 1 \\
\hline Finland & State ministry & 1 \\
\hline France & State ministry & 1 \\
\hline Germany & Federal and Länder ministries & 16 \\
\hline Greece & State ministry & 1 \\
\hline Hungary & State ministry & 1 \\
\hline Ireland & State ministry & 1 \\
\hline Italy & Departments in regional governments & 21 \\
\hline Latvia & State ministry & 1 \\
\hline Lithuania & State ministry & 1 \\
\hline Luxembourg & State ministry & 1 \\
\hline Malta & n.a. & n.a. \\
\hline Netherlands & State ministry & 1 \\
\hline Poland & State ministry & 1 \\
\hline Portugal & National Institute for Conservation and Forests & 1 \\
\hline Romania & State ministry & 1 \\
\hline Slovakia & State ministry & 1 \\
\hline Slovenia & State ministry & 1 \\
\hline Spain & State ministry and regional governments & 17 \\
\hline Sweden & State ministry & 1 \\
\hline United Kingdom & Department under state ministry and country ministries & 4 \\
\hline
\end{tabular}


The local level

The third level of governance involves stakeholders and actors in charge of managing forest landscapes. The main actors at the forest management unit and stand level, i.e. directly involved in forest management activities, are non-industrial and industrial private forest owners and their organisations, and managers of state, communal, church and military forests, as well as administrations of protected areas. At this level, in most of the countries the state also has public organisations controlling forest policy implementation in public and private forests.

The shares of private and public forests vary greatly among the EU MS. There is a general trend for more privately owned forest and wooded land in Western Europe than in Eastern Europe (Fig. 1), even if some countries have considerable variation (e.g., Sweden).
Around $60 \%$ of the EU's forests are in hands of about 16 million non-industrial private forest owners (CEPF 2009, European Commission 2013b, p. 20). Forest restitution processes took place in new MS, where forests were formerly state owned and increased the number of private forest owners (CEPF 2008). According to CEPF (2008), the extent of cooperation, measured by the membership in associations of private forest owners, varies from a couple percent to up to $40 \%$ of a total number of forest owners in a country. The largest shares of state-owned forests are found in Romania, Bulgaria and Poland. In the latter, about $80 \%$ of forests are state-owned and managed by one state company, which is subdivided into 17 regional directorates with 434 forest inspectorates. By contrast, in Austria, only $16 \%$ of the national forests are stateowned. Even though being managed by one state company, it operates in 76 districts under the

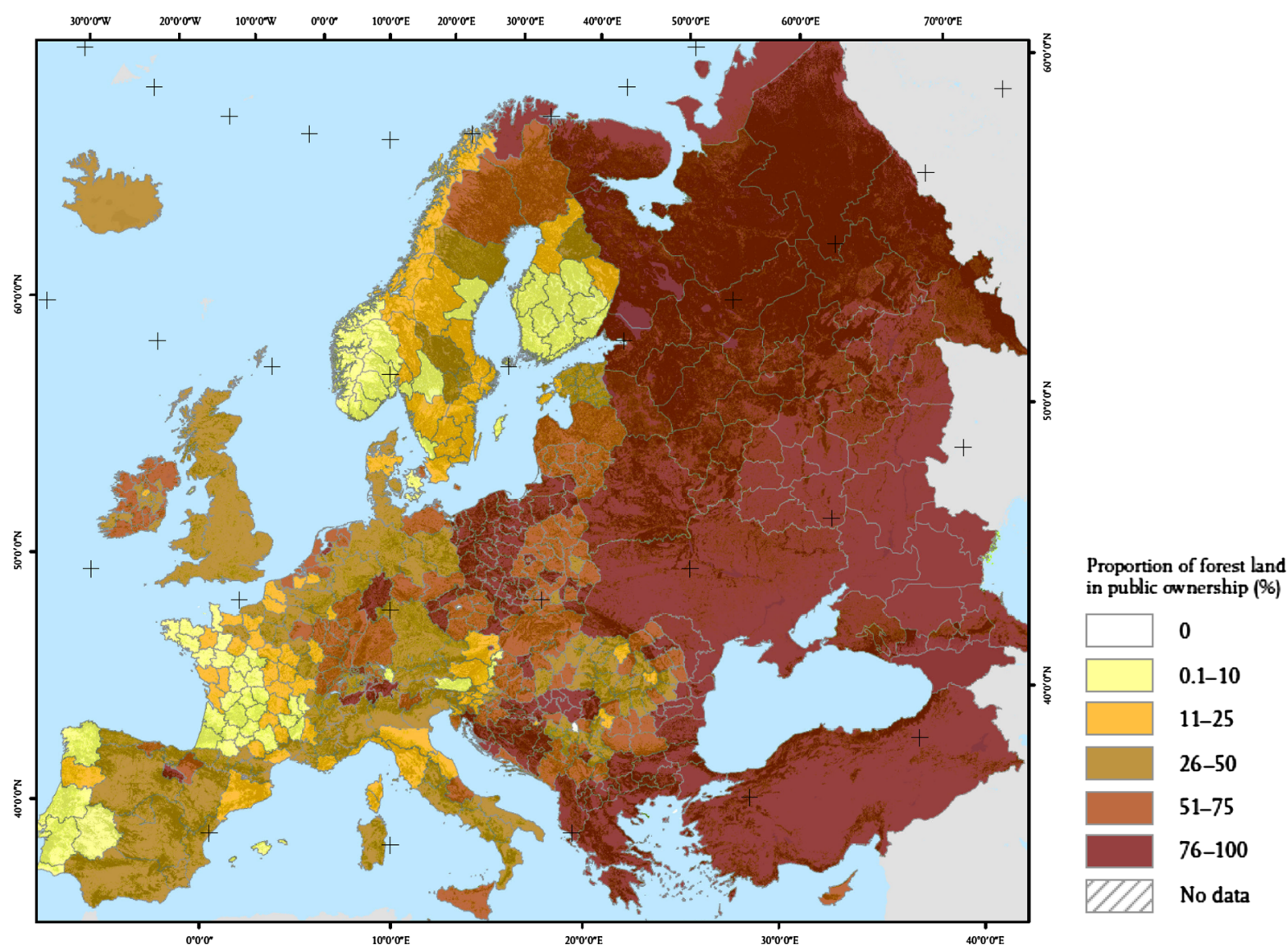

Fig. 1 Propotion of forest land owned by states according to Pulla et al. (2013; https://www.efi.int/publications-bank/ mapping-distribution-forest-ownership-europe); map from https://www.efi.int/sites/default/files/files/publication-bank/ 2018/public_forest_ownership_map_of_europe_april_2013. pdf 
implementing rules of the nine Austrian states. In Slovakia, $41 \%$ of public forests are under eight regional forest offices, with 40 district forest offices. In Lithuania, state forests are in transition from being managed by 42 state forest enterprises, subdivided into more than 350 forest administrative units, into one single state enterprise.

\section{Integrated landscape approach as a solution}

\section{Polycentric forest governance in the EU as an asset}

Forest governance in the EU takes place across multiple levels of decision-making, which is well grounded in the literature of forest governance (Weber 2017). Realising SFM policy on the ground relies on coordination across and within levels of government, both vertically and horizontally. While the EU does not have the capacity to steer forest policy itself, it is often argued that MS sectorial actors at multiple levels are important. Indeed, the polycentric and multi-level governance framework in the EU is characterized by a clear bias towards policy and decision-making actors and institutions operating at the national and subnational levels. The ninety national or sub-national governmental institutions have responsibilities for forest governance. National to local forestry administrations have the power to exercise direct planning, including an obligation to translate European policies to their own contexts. Nevertheless, due to the principle of subsidiarity, they have little opportunities to actively contribute to the design of EU policies (sensu Hofmann 2008). Across levels of decisionmaking, top-down coordination of policy objectives is difficult per se, mainly due to the wide range and diversity of forest owners and public administrations, often with different focus and culture depending on the regional and local context (Pülzl et al. 2013). This can become complex and hamper implementation even within a single regional and sub-regional level, where different administrative institutions and private actors with responsibilities for the forestry sector and other sectors affecting forest landscapes (e.g., forest productivity vs. nature conservation) are struggling with the coordination of decisions in a spatially explicit and synergistic way (Muñoz-Rojas et al. 2015). In these cases, an integrated landscape approach has frequently been advocated to resolve policy coordination and stakeholder cooperation at adequate functional levels and spatial scales (World Forestry Congress 2009; Axelsson et al. 2011; Sayer et al. 2013).

A wide range of EU policy objectives are directly or indirectly affecting forests and wooded land. Consequently, the capacity of the identified 90 units in the EU to govern, i.e. sensu Kjær (2004) to "steer and apply the rules of the game", is affected by developments in other policies with strong EU competence (e.g., Primdahl et al. 2018). Implementation of those policies sometimes benefits from well-established and efficient institutional arrangements, linking vertically EU-level priority setting and decision-making with the MS operational level, regions and other relevant spatial and institutional units (e.g., implementation of rural development as part of the agricultural policy) (European Communities 2006; European Commission 2008). However, integrated mechanisms for steering co-ordinated actions that more effectively contribute to operationalization of these goals are limited. First, the priorities expressed in the EU Forest Strategy are in no ways binding, despite the large amount of legislative instruments that are also forest-related, but linked to other policy areas (e.g., climate change, energy). Second, no policy instruments are in place to provide leverage for an EU-level steering of these priorities. It is thus clear that there is a lack of means to steer the developments in forest governance at an EU level, other than from a purely strategic perspective. It is equally clear that mechanisms for holding actors responsible for delivering forest governance accountable for their actions from a larger EU perspective, are also absent. Third, many "governance units" present on national and sub-national levels, comprise numerous public and private actors. All of which collectively need to coordinate their compliance with legislation adopted at the respective national or sub-national legislatures, and enforced by executives on the respective levels. Consequently, scale miss-matches often arise as a result of these gaps (Cumming et al. 2006), which hamper the efficiency of the whole framework.

To cope with these problems we argue that the principle of "empowered deliberative democracy" advocated by Fung and Wright (2001) should be considered. They suggest three principles to empower participatory governance: (1) practical orientation meaning that stakeholders' particular topics are in the focus; (2) bottom-up participation by relying upon 
the involvement of citizens and officials operating in the actual landscape; (3) generation of solutions that are defined through evidence-based reasoned deliberation. The institutional design properties necessary in order to advance these principles include: (a) devolving decisions and implementation capacity of actors operating at the lowest possible levels; (b) promoting and facilitating coordinated and cooperative supervision across different functional scales and units, importantly including landscape (when local action units are linked in order to allocate resources, solve common and cross-border problems, and diffuse innovation and learning); (c) enhancing public-private cooperation through more innovative and flexible governance and institutional arrangements. Additionally, Hajer (2003) argues that in order to render policy intervention under current governance frameworks more efficient, interactive practices of deliberation should be encouraged that are successful in building up a real co-construction of knowledge, whilst enhancing the levels of trust and credibility of the actors involved. This requires new modes of knowledge production and collaborative learning (Angelstam et al. 2017, 2018a).

Those ideas are mostly in line with the idea of cogovernance in polycentric systems (Ostrom 1990, 1999). The concept of poly-centricity was originally introduced by Ostrom et al. (1961) who argued that different decision-making foci may coexist independently from each other, thus creating productive governance arrangement despite state government. This has been confirmed through their empirical research. One of the insights is that local actors enjoy considerable self-governing capabilities, and that small- and medium-sized land-management units are important components of effective governance systems. Ostrom (2009) points out that trust and reciprocity are core elements, since under polycentric governance systems citizens and companies have to trust that others elsewhere exercise the same governance approach to forests, and that free riding is banned. The polycentric approach also allows improved understanding of the conditions for interactive learning across different governance levels, according to Andersson and Ostrom (2008). This is essential to understand what is actually working on the ground (and not) under different conditions, and also how evidence-based knowledge can be blended in with local and indigenous knowledge to device more effective solutions. Finally, Aligica and Tarko (2012) summarise three basic features of the polycentric governance: (1) a multiplicity of decision centres, (2) overarching system of rules (not necessarily legal) and (3) a spontaneous order. This is well aligned with landscape stewardship and governance that is adapted to both the regional profile of ecosystem services that originates from forest and other wooded land, and the land ownership structure at regional and local levels.

Place-based deliberation through landscape approach

As noted by Aggestam and Pülzl (2018), the number of different EU policy instruments and sectoral interests both upstream and downstream on the forest value chain presents an enormous complexity, thus resulting in conflicting objectives on the ground (c.f. MuñozRojas et al. 2015; EASAC 2017). The portfolios of challenges to implement sustainable forest management through policies and planning depend on the social-ecological context. In particular, the integrated cross-scalar and spatially explicit coordination of management and planning in local landscapes and regions can be defined as "wicked problems". Therefore, to simultaneously deliver wood and biomass production, biodiversity conservation and socio-cultural values is a major unresolved challenge (Triviño et al. 2015; EASAC 2017).

Policy implementation needs to better account for the multi-functionality of forests by integrating social, economic and ecological objectives through collaborative spatial planning (e.g., Primdahl et al. 2018). This requires management approaches, which are adapted to the regional context (e.g., Elbakidze et al. 2017; Naumov et al. 2018). However, management approaches for forest and wooded land developed in one region may not be directly transferable to other biophysical, socio-economic and cultural and political contexts. For example, forest management methods, such as continuous cover silviculture, enhancement of native tree species diversity and design of sustainable landscape structures may contribute differently to enhancing direct economic benefits, to the conservation of carbon stocks and biodiversity, and to the improvement of the social and cultural forest landscape values, depending on the context (EASAC 2017). The large number of governance units in the 
Table 2 Whereas OECD's (2006) New Rural Paradigm provided a conceptual framework, the current Rural Policy 3.0 (OECD 2017) focuses on identifying more specific mechanisms for the implementation of effective rural policies and practices. This is consistent with landscape approach

\begin{tabular}{|c|c|c|c|}
\hline & Old paradigm & New rural paradigm (2006) & Rural Policy 3.0-implementing the new rural paradigm \\
\hline Objectives & Equalisation & Competiveness & $\begin{array}{l}\text { Well-being considering multiple dimensions of: (i) the } \\
\text { economy, (ii) society and (iii) the environment }\end{array}$ \\
\hline Policy focus & $\begin{array}{l}\text { Support for a single } \\
\text { dominant } \\
\text { resource sector }\end{array}$ & $\begin{array}{l}\text { Support for multiple sectors based } \\
\text { on their competitiveness }\end{array}$ & $\begin{array}{l}\text { Low-density economies differentiated by type of rural } \\
\text { area }\end{array}$ \\
\hline Tools & Subsidies for firms & $\begin{array}{l}\text { Investments in qualified firms and } \\
\text { communities }\end{array}$ & $\begin{array}{l}\text { Integrated rural development approach-spectrum of } \\
\text { support to public sector, firms and third sector }\end{array}$ \\
\hline $\begin{array}{r}\text { Key actors \& } \\
\text { stakeholders }\end{array}$ & $\begin{array}{l}\text { Farm organisations } \\
\text { and national } \\
\text { governments }\end{array}$ & $\begin{array}{l}\text { All levels of government and all } \\
\text { relevant departments plus local } \\
\text { stakeholders }\end{array}$ & $\begin{array}{l}\text { Involvement of: (i) public sector-multi-level } \\
\text { governance, (ii) private sector-for-profit firms and } \\
\text { social enterprise, and (iii) third sector-non- } \\
\text { governmental organisations and civil society }\end{array}$ \\
\hline $\begin{array}{l}\text { Policy } \\
\text { approach }\end{array}$ & $\begin{array}{l}\text { Uniformly applied } \\
\text { top down policy }\end{array}$ & Bottom-up policy, local strategies & Integrated approach with multiple policy domains \\
\hline $\begin{array}{l}\text { Rural } \\
\text { definition }\end{array}$ & Not urban & $\begin{array}{l}\text { Rural as a variety of distinct types } \\
\text { of place }\end{array}$ & $\begin{array}{l}\text { Three types of rural: (i) within a functional urban area, } \\
\text { (ii) close to a functional urban area, and (iii) far from a } \\
\text { functional urban area }\end{array}$ \\
\hline
\end{tabular}

EU is therefore an asset for developing regionally adapted solutions.

To maintain territorial capital, including its cultural, natural and socio-economic benefits (Faludi and Peyrony 2011) and enhance human well-being, modified landscapes often require capacity building in social systems towards maintenance and restoration of landscapes (Wu 2013) as social-ecological systems (Dawson et al. 2017). This involves both place-based modification of the biophysical environment, coordination of human management of land and water, and motivation of stakeholders and actors to act sustainably, all within an agenda that is fully based on coordination and cooperation. The term landscape approach captures this (Sayer et al. 2015). Axelsson et al. (2011) presented a practical operationalization of landscape approach using five core attributes that should be satisfied: (1) a sufficiently large area that matches management requirements and challenges to deliver desired goods, services and values, (2) multilevel and multi-sector stakeholder collaboration that promotes sustainable development as a social process, (3) commitment to and understanding of sustainability as an aim among stakeholders, (4) integrative knowledge production, and (5) sharing of experience, results and information, to develop local tacit and general explicit knowledge.
Biosphere Reserve (Batisse 1982), Ecomuseum (Davis 2011), Long-Term Socio-Ecological Research platform (Singh et al. 2013; Angelstam et al. 2019b), Model Forest (IMFN 2008; Bonnell 2012) and Living Lab (Dell'Era and Landoni 2014) are five examples that are consistent with a landscape approach (World Forestry Congress 2009; Axelsson et al. 2011; Sayer et al. 2013, 2015; Angelstam and Elbakidze 2017). Such concepts, and initiatives to realise them on the ground in actual landscapes, reflect the transition towards area-based rural development programmes (e.g., Giessen 2010; OECD 2017, Table 2). These now advocate regional governance of collaborative development processes involving forestry, agriculture and water in regionally specific social-ecological systems. Collaborative learning among multiple landscape approach concepts, and initiatives applying those in landscapes on the ground, needs to be encouraged by effective bridging of barriers in terms of competition between organizations and concepts that focus only on their own version of what an integrated landscape approach means.

\section{Conclusions}

Like all sectors historically based on tangible natural resources, forestry is currently expected to deliver 
multiple ecosystem services, including both material and immaterial benefits. Policies on bioenergy, bioeconomy, rural development, green infrastructure, biodiversity and water overlap with sustainable forest management (SFM) policy, and entail multiple and often competing objectives. Our analysis demonstrates that the forest governance in the $\mathrm{EU}$ is polycentric, dominated by around 90 national or subnational governing bodies. This makes EU-level coordination difficult. However, this diversity also offers opportunities for development of regionally adapted place-based co-ordination among policies. Forest and other wooded land are constituent elements of social-ecological systems, i.e. landscapes. Both among and within EU Member States there is a diversity of social system legacies, political cultures, landscape histories and governance arrangements, and also variation in the desired profiles of benefits on the one hand, and opportunities to deliver those benefits on the other. To effectively translate EU-wide SFM and SFM-related policies to action on the ground we highlight the need to apply regionally and locally adapted landscape approaches that consider different land ownership structures, interests, values and knowhows of all those involved, and engages all actors in capacity building and mutual learning. This (1) could render implementation of EU-wide objectives more effective, transparent and sustainable, and (2) would add legitimacy and local ownership to the newly formulated, refined, and prioritised EU-wide policy objectives itself.

Acknowledgements Open access funding provided by Swedish University of Agricultural Sciences. Funding was granted from Marcus and Amalia Wallenbergs Minnesfond and from the Swedish Research Council FORMAS [Grant Nos. 2011-1737 and 2017:1342] to Per Angelstam. We thank José Muñoz-Rojas and Fátima Cruz for inspiring comments. This manuscript represents solely the views of its authors and cannot in any circumstances be regarded as the official position of the European Commission.

Open Access This article is distributed under the terms of the Creative Commons Attribution 4.0 International License (http:// creativecommons.org/licenses/by/4.0/), which permits unrestricted use, distribution, and reproduction in any medium, provided you give appropriate credit to the original author(s) and the source, provide a link to the Creative Commons license, and indicate if changes were made.

\section{References}

Aggestam F, Pülzl H (2018) Coordinating the uncoordinated: the EU Forest Strategy. Forests 9(3):125

Aggestam F, Pülzl H, Sotirov M, Winkel G (2017) The EU policy framework. In: Winkel G (ed) Towards a sustainable European forest-based bioeconomy-assessment and the way forward. What Science Can Tell Us. European Forest Institute, Joensuu, pp 19-35

Agnoletti M (ed) (2013) Italian historical rural landscapes. Cultural values for the environment and rural development. Springer, Dordrecht

Aligica PD, Tarko V (2012) Polycentricity: from Polanyi to Ostrom, and beyond. Governance 25(2):237-262

Andersson KP, Ostrom E (2008) Analyzing decentralized resource regimes from a polycentric perspective. Policy Sci 41(1):71-93

Angelstam P, Andersson K, Axelsson R, Elbakidze M, Jonsson B-G, Roberge J-M (2011) Protecting forest areas for biodiversity in Sweden 1991-2010: policy implementation process and outcomes on the ground. Silva Fennica 45(5):1111-1133

Angelstam P, Barnes G, Elbakidze M, Marsh A, Marais C, Mills A, Polonsky S, Richardson DM, Rivers N, Shackleton R, Stafford W (2017) Collaborative learning to unlock investments for functional ecological infrastructure: bridging barriers in social-ecological systems in South Africa. Ecosyst Serv 27:291-304

Angelstam P, Elbakidze M (2017) Forest landscape stewardship for functional green infrastructures in Europe's West and East: diagnosing and treating social-ecological systems. In: Bieling C, Plieninger T (eds) The science and practice of landscape Stewardship. Cambridge University Press, Cambridge, pp 124-144

Angelstam P, Elbakidze M, Lawrence A, Manton M, Melecis V, Pereira A (2018a) Barriers and bridges for landscape stewardship and knowledge production to sustain functional green infrastructures. In: Pereira A, Peterson U, Pastur G, Iverson L (eds) Ecosystem services from forest landscapes. Springer, Berlin, pp 127-167

Angelstam P, Grodzynskyi M, Andersson K, Axelsson R, Elbakidze M, Khoroshev A, Kruhlov I, Naumov V (2013) Measurement, collaborative learning and research for sustainable use of ecosystem services: landscape concepts and Europe as laboratory. Ambio 42(2):129-145

Angelstam P, Munoz-Rojas J, Pinto-Correia T (2019a) Landscape concepts and landscape approach can foster knowledge production and learning that sustain multiple ecosystem services. Landscape Ecol. https://doi.org/10. 1007/s10980-019-00866-z

Angelstam P, Manton M, Elbakidze M, Sijtsma F, Adamescu M, Avni N, Beja P, Bezak P, Zyablikova I, Cruz F, Bretagnolle V, Díaz-Delgado R, Ens B, Fedoriak M, Flaim G, Gingrich S, Lavi-Neeman M, Medinets S, Melecis V, Muñoz-Rojas J, Schäckermann J, Stocker-Kiss A, Setälä H, Stryamets N, Taka M, Tallec G, Tappeiner U, Törnblom J, Yamelynets T (2019b) LTSER platforms as a place-based transdisciplinary research infrastructure: learning landscape approach through evaluation. Landscape Ecol. https://doi. org/10.1007/s10980-018-0737-6 
Angelstam P, Naumov V, Elbakidze M, Manton M, Priednieks J, Rendenieks Z (2018b) Wood production and biodiversity conservation are rival forestry objectives in Europe's Baltic Sea Region. Ecosphere. https://doi.org/10.1002/ ecs2.2119

Angelstam P, Persson R, Schlaepfer R (2004) The sustainable forest management vision and biodiversity-barriers and bridges for implementation in actual landscapes. Ecol Bull 51:29-49

Axelsson R, Angelstam P, Elbakidze M, Stryamets N, Johansson K-E (2011) Sustainable development and sustainability: landscape approach as a practical interpretation of principles and implementation concepts. J Landsc Ecol 4(3):5-30

Batisse M (1982) The biosphere reserve: a tool for environmental conservation and management. Environ Conserv 9(2):101-111

Beland Lindahl K, Sténs A, Sandström C, Johansson J, Lidskog R, Ranius T, Roberge J-M (2017) The Swedish forestry model: more of everything? For Policy Econ 77:44-55

Bell S, Hindmoor A (2009) Rethinking governance: the centrality of the state in modern society. Cambridge University Press, Cambridge

Bell S, Hindmoor A (2012) Governance without government? The case of the forest Stewardship council. Public Admin 90:1

Bohn U, Gollub G, Hettwer C (2000) Map of the natural vegetation of Europe. Explanatory text with CD-ROM. Federal Agency for Nature Conservation, Bonn-Bad Gotesberg

Bonnell B (2012) Trends in research and collaboration in the Canadian Model Forest Network, 1993-2010. For Chron 88(3):274-282

Cambero C, Sowlati T (2014) Assessment and optimization of forest biomass supply chains from economic, social and environmental perspectives - a review of literature. Renew Sustain Energy Rev 36:62-73

CEPF (Confederation of Private Forest Owners) (2008) European Forest Owner Organisations. Forest Owner Cooperation: Main figures, aims and goals. Report of a study conducted by Confederation of European Forest Owners

CEPF (Confederation of Private Forest Owners) (2009) Information provided on the website of Confederation of European Forest Owners (CEPF), http://www.cepf-eu.org

Commission of the European Communities (2003) Communication from the Commission to the Council and the European Parliament-Forest Law Enforcement, Governance and Trade (FLEGT)_Proposal for an EU Action Plan. $\operatorname{COM}(2003) 251$ final

Commission of the European Communities (2005a) Communication from the Commission to the Council and the European Parliament "Reporting on the implementation of the EU Forestry Strategy". COM(2005) 84 final

Commission of the European Communities (2005b) Commission Staff Working Document, annex to the Communication from the Commission to the Council and the European Parliament "Reporting on the implementation of the EU Forestry Strategy". COM(2005) 84 final

Commission of the European Communities (2005c) Communication from the Commission of 7 December 2005Biomass Action Plan. COM (2005) 628 final (OJ C 49 of 28.02.2005)
Commission of the European Communities (2006) Communication from the Commission to the Council and the European Parliament on an EU Forest Action Plan. COM(2006) 302 final

Council of the European Union (1999) Council Resolution on a Forestry Strategy for the European Union. Official Journal C56, 26.2.1999, p. 1

Cumming GS, Cumming DHM, Redman CL (2006) Scale mismatches in social-ecological systems: causes, consequences, and solutions. Ecol Soc 11(1):14

Davis P (2011) Ecomuseums: a sense of place. Continuum International Publishing Group, London

Dawson L, Elbakidze M, Angelstam P, Gordon J (2017) Governance and management dynamics of landscape restoration at multiple scales: learning from successful environmental managers in Sweden. J Environ Manage 197:24-40

Dell'Era C, Landoni P (2014) Living Lab: a methodology between user-centred design and participatory design. Creat Innov Manag 23(2):137-154

Dittrich A, von Wehrden H, Abson DJ, Bartkowski B, Cord AF, Fust P, Hoyer C, Kambach S, Meyer MA, Radzeviciute R, Nieto-Romero M, Seppelt R, Beckmann M (2017) Mapping and analysing historical indicators of ecosystem services in Germany. Ecol Ind 75:101-110

Duckett D, Feliciano D, Martin-Ortega J, Munoz-Rojas J (2016) Tackling wicked environmental problems: the discourse and its influence on praxis in Scotland. Landsc Urban Plann 154:44-56

EASAC (2017) Multi-functionality and sustainability in the European Union's forests. European Academies' Science Advisory Council (EASAC) report 32

Edwards P, Kleinschmit D (2013) Towards a European forest policy—conflicting courses. For Policy Econ 33:87-93

Elbakidze M, Angelstam P (2007) Implementing sustainable forest management in Ukraine's Carpathian Mountains: the role of traditional village systems. For Ecol Manage 249:28-38

Elbakidze M, Angelstam P, Yamelynets T, Dawson L, Gebrehiwot M, Stryamets N, Johansson K-E, Garrido P, Naumov V, Manton M (2017) A bottom-up approach to map land covers as potential green infrastructure hubs for human well-being in rural settings: a case study from Sweden. Landsc Urban Plann 168:72-83

European Commission (2008) The EU rural development policy: facing the challenges. European Communities

European Commission (2009) Report on implementation of forestry measures under the rural development Regulation 1698/2005 for the period 2007-2013. http://ec.europa.eu/ agriculture/fore/publi/index_en.htm

European Commission (2013a) A new EU Forest Strategy: for forests and the forest-based sector. Communication from the Commission to the European Parliament, the Council, the European Economic and Social Committee and the Committee of the Regions. COM (2013) 659 final

European Commission (2013b) Commission staff working document Accompanying the document on A new EU Forest Strategy: for forests and the forest-based sector Communication from the Commission to the European Parliament, the Council, the European Economic and 
Social Committee and the Committee of the Regions. SWS (2013) 342 final

European Communities (2006) The EU Rural Development Policy 2007-2013. Fact Sheet. European Communities

European Parliament and of the Council of the European Union (2010) Regulation (EU) No 995/2010 of the European Parliament and of the Council of 20 October 2010 laying down the obligations of operators who place timber and timber products on the market Text with EEA relevance

European Science Foundation (2010) Landscape in a changing world. Bridging divides, integrating disciplines, serving society. Science Policy Briefing 41, European Science Foundation, Strasbourg

Eurostat (2008) Forest-based industries in the EU-27. Eurostat, Statistics in focus 74/2008

Eurostat (2017) Agriculture, forestry and fishery statistics. Publications Office of the European Union, Luxembourg

Faludi A, Peyrony J (2011). Cohesion policy contributing to territorial cohesion - Future scenarios, European Journal of Spatial Development, Refereed article No. 43. Accessed 04 Nov 2018 http://www.nordregio.se/Global/EJSD/ Refereed\%20articles/refereed43.pdf

Fung A, Wright EO (2001) Deepening democracy: innovations in empowered participatory governance. Politics Soc 29:5-42

Giessen L (2010) Regional forest governance. Potentials for forestry and political drivers in integrated rural development policy. Universitätsverlag Göttingen

Grodzynskyi MD (2005) Piznannia Landshaftu: Misce i Prostir [Understanding landscape: Place and space]. Two volumes. Kiev: Kiev University Publishing House (in Ukrainian)

Gustavsson L, Sathre R (2006) Variability in energy and carbon dioxide balances of wood and concrete building materials. Build Environ 41(7):940-951

Hajer MA (2003) Policy without polity? Policy analysis and the institutional void. Policy Sci 36(2): 175-195

Head BW (2008) Wicked problems in public policy. Public Policy 3(2):101-118

Hofmann HCH (2008) Mapping the European administrative space. West European Politics 31(4):662-676

IMFN (2008) Model forest development guide. International Model Forest Network Secretariat, Ottawa

Kennedy JJ, Thomas JW, Glueck P (2001) Evolving forestry and rural development beliefs at midpoint and close of the 20th century. For Policy Econ 3(1-2):81-95

Kirby KJ, Watkins D (eds) (2015) Europe's changing woods and forests: from wildwood to cultural landscapes. CABI, Wallingford

Kjaer AM (2004) Governance. Polity Press, Cambridge

Koppenjan J, Klijn E-H (2004) Managing Uncertainties in Networks; a network approach to problem solving and decision-making. Routledge, London

Lazdinis M, Angelstam P, Lazdinis I (2009) Governing forests of the European Union: institutional framework for interest representation. Environ Policy Gov 19:44-56

Lindelöw D (2018) Running to stand still - the role of travel time in transport planning. Sweco, Gothenburg

McCormick K, Kautto N (2013) The bioeconomy in Europe: an overview. Sustainability 5(6):2589-2608
MCPFE (2006) Cultural heritage and sustainable forest management: The role of traditional knowledge. In: Proceedings of the conference 8-11 June, 2006, Florence, Italy. Volumes 1 and 2. Warszawa

Muñoz-Rojas J, Nijnik M, González-Puente M, Cortines-García F (2015) Synergies and conflicts in the use of policy and planning instruments for implementing forest and woodland corridors and networks; a case study in NE Scotland. For Policy Econ 57:47-64

Naumov V, Manton M, Elbakidze M, Rendenieks Z, Priedniek J, Uglyanets S, Zhivotov A, Angelstam P (2018) How to reconcile wood production and biodiversity conservation? The Pan-European boreal forest history gradient as an "experiment". J Environ Manag 218:1-13.

OECD (2006) The new rural paradigm. OECD Publications, Paris

OECD (2017) New rural policy: linking up for growth. OECD Publications, Paris. Accessed 31 Mar 2018 at http://www. fao.org/family-farming/detail/en/c/522521/

Ostrom E (1990) Governing the commons: the evolution of institutions for collective action. Cambridge University Press, Cambridge

Ostrom V (1999) Polycentricity (part 1). In: McGinnis MD (ed) Polycentricity and local public economies: readings from the workshop in political theory and policy analysis. University of Michigan Press, Ann Arbor, pp 52-74

Ostrom E (2009) A polycentric approach for coping with climate change. World Bank, Washington, DC

Ostrom V, Tiebout CM, Warren R (1961) The organization of government in metropolitan areas: a theoretical inquiry. Am Polit Sci Rev 55(4):831-842

Parrotta J, Trosper R (eds) (2012) Traditional forest-related knowledge: sustaining communities, ecosystems and biocultural diversity, vol 12. Series world forests. Springer, Dordrecht, pp 251-279

Pelli P, Aggestam F, Weiss G, Inhaizer H, Heikkinen J, Keenleyside C, Gantioler S, Boglio D, Poláková J (2012) Expost evaluation of the EU Forest Action Plan. European Forestry Institute, Joensuu, http://ec.europa.eu/agriculture/ evaluation/market-and-income-reports/forest-action-plan2012_en.htm

Pierre J, Peters GB (eds) (2000) Governance, politics and the state. Macmillan, Houndmills/Basingstoke

Primdahl J, Kristensen L, Arler F, Angelstam P, Aagaard Christensen A, Elbakidze M (2018) Rural landscape governance and expertise - on landscape agents and democracy. In: Egoz S, Jorgensen K, Ruggeri D (eds) Defining landscape democracy: a path to spatial justice. Edward Elgar Publishing, Cheltenham, pp 153-164

Puettmann KJ, Coates KD, Messier CC (2012) A critique of silviculture: managing for complexity. Island press, Washington DC

Pulla P, Schuck A, Verkerk PJ, Lasserre B, Marchetti M, Green $\mathrm{T}$ (2013) Mapping the distribution of forest ownership in Europe. European Forest Institute, Joensuu

Pülzl H, Hogl K, Kleinschmit D, Wydra D, Arts B, Mayer P, Palahi M, Winkel G, Wolfslehner B (eds) (2013) European forest governance: issues at stake and the way forward. EFI Series: what science can tell us. EFI, Joensuu 
Pülzl H, Kleinschmit D, Arts B (2014) Bioeconomy-an emerging meta-discourse affecting forest discourses? Scand J For Res 29(4):386-393

Pülzl H, Wydra D, Hogl K (2018) Piecemeal integration: explaining and understanding 60 years of European Union Forest Policy-Making. Forests 2018(9):719

Rauschmayer F, Berghöfer A, Omann I, Zikos D (2009) Examining processes or/and outcomes? Evaluation concepts in European governance of natural resources. Environ Policy Govern 19(3):159-173

Rhodes RAW (1996) The new Governance: governing without government. Polit Stud 44(4):652-667

Rhodes RAW (1997) Understanding governance. Open University Press, Milton Keynes

Rhodes RAW (2007) Understanding governance: ten years on'. Org Stud 28(8):1243-1264

Salamon L (ed) (2002) The tools of government: a guide to the new governance. Oxford University Press, Oxford

Sayer J, Margules C, Boedhihartono AK, Dale A, Sunderland T, Supriatna J, Saryanthi R (2015) Landscape approaches; what are the pre-conditions for success? Sustain Sci $10(2): 345-355$

Sayer J, Sunderland T, Ghazoul J, Pfund JL, Sheil D, Meijaard E, Venter M, Boedhihartono AK, Day M, Garcia C, van Oosten C (2013) Ten principles for a landscape approach to reconciling agriculture, conservation, and other competing land uses. Proc Natl Acad Sci USA 110(21):8349-8356

Simpson M, Pichler V, Tyrvainen L, Collins K, Martin S, Strange N, Vuletic D (2008). The economic and social values of forests for recreation and nature tourism: a research overview. COST Action E33: Forests for Recreation and Nature Tourism (FORREC). European Commission, COST and European Science Foundation

Singh SJ, Haberl H, Chertow M, Mirtl M, Schmid M (2013) Introduction. In: Haberl H, Chertow M, Mirtl M, Schmid M, Singh SJ (eds) Long term socio-ecological research: Studies in society-nature interactions across spatial and temporal scales. Springer Science and Business Media, Berlin, pp 1-26

Triviño M, Juutinen A, Mazziotta A, Miettinen K, Podkopaev D, Reunanen P, Mönkkönen M (2015) Managing a boreal forest landscape for providing timber, storing and sequestering carbon. Ecosyst Serv 14:179-189

Weber N (2017) Implementation of forest policies: challenges, deficits and failures in European multi-level systems. For Policy Econ 82:1-60

World Forestry Congress (2009) Forest development: a vital balance, findings and strategic actions. Findings and strategic actions. http://foris.fao.org/meetings/download/_ 2009/xiii_th_world_forestry_congress/misc_documents/ wfc_declaration.pdf

Wu J (2013) Landscape sustainability science: ecosystem services and human well-being in changing landscapes. Landscape Ecol 28(6):999-1023

Publisher's Note Springer Nature remains neutral with regard to jurisdictional claims in published maps and institutional affiliations. 